\title{
Natural killer cell reconstitution after hematopoietic stem-cell transplantation in children
}

\author{
Israel Parra-Ortega, ${ }^{1}$ Noemí Nájera-Martínez, ${ }^{1}$ Félix Gaytán-Morales, ${ }^{2}$ Iván Castorena-Villa, ${ }^{2}$ \\ Catalina Cortés-Flores, ${ }^{2}$ Briceida López-Martínez, ${ }^{3}$ Vianney Ortiz-Navarrete, ${ }^{4}$ and Irlanda Olvera-Gómez ${ }^{5}$ \\ ${ }^{1}$ Hospital Infantil de México Federico Gómez, Clinical Laboratory Department, Mexico City; ${ }^{2}$ Hospital Infantil de México Federico Gómez, Hematopoietic \\ Stem Cell Transplantation Unit, Mexico City; ${ }^{3}$ Hospital Infantil de México Federico Gómez, Sub-directorate of Auxilliary Services and Diagnosis, \\ Mexico City; ${ }^{4}$ Center of Research and Advanced Studies, Molecular Biomedicine, Mexico City; ${ }^{5}$ Universidad Anáhuac Norte, State of Mexico. Mexico
}

\begin{abstract}
Introduction: After hematopoietic stem cell transplantation (HSCT), natural killer (NK) cells reconstitution is the main barrier against viral infections. Objective: To determine that the knowledge on the kinetics of NK cell reconstitution after HSCT contributes to transplant efficient monitoring, which increases the possibility of its success. Method: Twenty-one patients undergoing HSCT were included, as well as a control group of clinically healthy individuals. At different time points after transplantation (range of 21 to 670 days), CD3- CD16+ CD56+ NK cells were quantified by flow cytometry in peripheral blood samples. Results: NK cell recovery occurs at three to six months and 10 to 12 months post-transplantation; their number was significantly lower (in comparison with the control group) in the rest of the monitoring time. Conclusions: The first period of NK cell recovery occurs between three and six months after transplantation. Reconstitution is transient and the number of NK cells varies in the first years.
\end{abstract}

KEY WORDS: Natural killer cells. Transplantation. Hematopoietic cells. Cell reconstitution.

\section{Reconstitución de células natural killer después del trasplante de células progenitoras hematopoyéticas en niños}

\section{Resumen}

Introducción: Después de un trasplante de células progenitoras hematopoyéticas (TCPH), la reconstitución de las células natural killer (NK) es la principal barrera contra las infecciones virales. Objetivo: Determinar que el conocimiento sobre la cinética de la reconstitución de las células NK posterior al TCPH contribuye a un eficiente monitoreo del trasplante, lo que incrementa la posibilidad de éxito de este. Método: Se incluyeron 21 pacientes sometidos a TCPH, así como un grupo control de individuos clínicamente sanos. En diferentes momentos después del trasplante (intervalo de 21 a 670 días), mediante citometría de flujo se cuantificaron las células NK CD3-CD16+CD56+ en muestras de sangre periférica. Resultados: La recuperación de las células NK ocurre a los tres a seis meses y a los 10 a 12 meses postrasplante; su número fue significativamente menor (en comparación con el grupo control) en el tiempo restante del monitoreo. Conclusiones: El primer periodo de recuperación de las células NK ocurre entre los tres y seis meses posteriores al trasplante. La reconstitución es transitoria y el número de células NK varía en los primeros años.

PALABRAS CLAVE: Células natural killer. Trasplante. Células hematopoyéticas. Reconstitución celular.

Correspondence:

*Irlanda Olvera-Gómez

E-mail: irlanda.olvera@salud.gob.mx
Gac Med Mex. 2020;156:187-193

Contents available at PubMed

www.gacetamedicademexico.com

0016-3813/@ 2020 Academia Nacional de Medicina de México, A.C.. Published by Permanyer. This is an open access article under the CC BY-NC-ND license (http://creativecommons.org/licenses/by-nc-nd/4.0/). 


\section{Introduction}

Natural killer (NK) cells are generated from a lymphoid precursor originating in bone marrow progenitor cells. ${ }^{1,2}$ Their morphology is similar to that of $T$ and $B$ lymphocytes, but they are profusely granulated and are identified by the absence of CD3 (a molecule that is exclusive to $\mathrm{T}$ lymphocytes) and CD16 and CD56 expression (more than $90 \%$ of NK cells in peripheral blood express both), although there are subpopulations with the CD16CD56+ and CD16+ CD56- phenotypes, which constitute between 5 and $10 \%$ of the total numbers of this type of cells. ${ }^{3}$ NKs are the first defense barrier against pathogens (mainly viruses) and tumor cells. Their activation and inhibition occurs after the recognition of human leukocyte antigen (HLA) alleles through immunoglobulin-like receptors that inhibit killer cells, which can interact with a single HLA allele or with several. ${ }^{4}$

Regardless of the graft source (bone marrow, mobilized peripheral blood, or umbilical cord cells), reconstitution of the NK cell population is achieved one to two months after allogeneic hematopoietic stem cell transplantation (HSCT). In general, NK cells that are generated during this period do not derive from the expansion of mature NK cells of the graft, but mainly from differentiation and maturation of progenitor cells. ${ }^{5-8}$

Furthermore, in allogeneic transplants, alloreactivity of graft cells ${ }^{9-11}$ (mature cells) or of those generated in the recipient after HSCT can occur, which is an event that can have a cytotoxic effect on the tumor cells that resisted or reappeared after HSCT. ${ }^{12}$

Reconstitution of innate immunity cells is critical in immunosuppressed patients, as well as in allogeneic or autologous HSCT recipients, owing to their role in infection control. In the latter case, since the reconstitution of $\mathrm{T}$ and $\mathrm{B}$ cells requires at least six months, prompt recovery of cell lines associated with the control of pathogens, such as NK cells, is relevant.

NK cell reconstitution after HSCT requires time to achieve homeostasis of this cell line in the first years after allogeneic transplantation. Monitoring of this process will contribute to a comprehensive assessment of the transplant recipient, by including laboratory tests and clinical follow-up, in order to increase the possibility for the procedure to be successful.

\section{Method}

An observational, prospective and descriptive study of children undergoing allogeneic HSCT between January
2017 and January 2018 was carried out at the Stem Cell Transplantation Unit and the Clinical Laboratory of the Children's Hospital of Mexico "Federico Gómez". The protocol was approved by the Research, Ethics and Biosafety Committees of the hospital. Parents, legal guardians or caregivers granted written consent after being informed on the purposes of the research.

The patients received a myeloablative conditioning or reduced-intensity regimen (according to the underlying pathology), and subsequently were infused at least one dose of $2 \times 10^{6} \mathrm{CD} 34+$ cells $/ \mathrm{kg}$ of body weight. A control group $(n=20)$, made up of clinically healthy individuals, with no fever, or infection diagnosis or on treatment with antibiotics or antivirals in the previous five days, was included.

From day 21 to day 670 of the post-transplantation stage, approximately $1 \mathrm{~mL}$ of peripheral blood was collected from each individual. Blood count was carried out on a Coulter LH $780^{\circledR}$ equipment (Beckman Coulter, Brea, CA, USA) in order to determine leukocyte total count, as well as the percentage of lymphocytes of the individual. NK cell phenotyping and quantification (CD3- CD16+ CD56+) were performed by flow cytometry; at least 50,000 cells were analyzed. NK cell determinations were made and absolute values (number of cells per liter) were calculated. In addition, HLA genotyping data, which was previously obtained at the Histocompatibility Laboratory, were collected.

\section{Results}

During the period from January 2017 to January 2018, 21 patients undergoing HSCT were included. The diagnoses they were referred to the Hematopoietic Stem Cell Transplantation Unit for were the following: acute lymphoblastic leukemia, $38.09 \%(n=8)$; medullary aplasia, $28.57 \%(n=6)$; acute myeloid leukemia, $19.04 \%(n=4)$; other solid tumors, $14.28 \%$ $(n=3)$ (Fig. 1); nine patients (43\%) were males and $12(57 \%)$ were females; age ranged from one to 17 years (Table 1).

Some patients received a myeloablative regimen, while others received a reduced-intensity regimen (depending on the underlying pathology) prior to allogeneic peripheral blood hematopoietic stem cell transplantation, after mobilization with granulocyte-colony stimulating factor. Compatibility between donor and recipient was defined based on HLA-A, HLA-B, HLA-C and HLA-DP alleles genotyping in two patients, and in the remaining 19, HLA-DQ and HLA-DR were also 


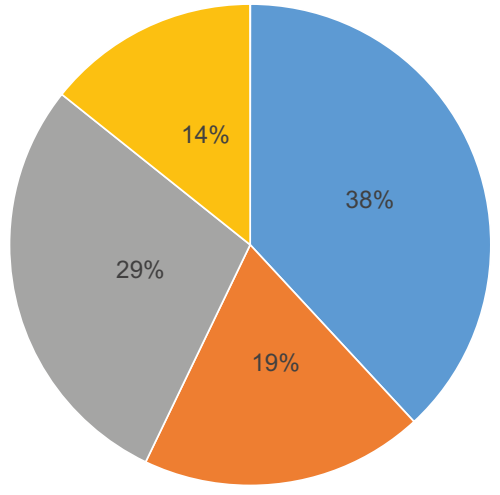

- Acute Lymphoblastic Leukemia - Acute Myeloid Leukemia

- Medullary Aplasia - Other (Solid tumors)

Figure 1. Diagnoses hematopoietic stem cell transplantation was carried out for.

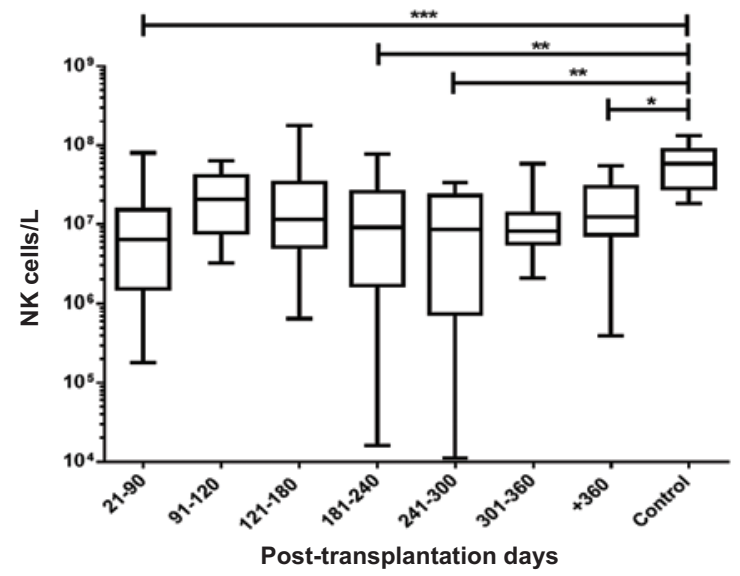

Figure 2. NK cell reconstitution kinetics after hematopoietic stem cell transplantation. Values were transformed to logarithms, and the p-values according to Kruskal-Wallis test $(p<0.001)$ and the multiple comparison are presented. ${ }^{*} p=0.043,{ }^{* *} p=0.0059$, ${ }^{* * *} p<0.0001$.

analyzed. Table 2 shows the shared alleles and if it was a haploidentical transplantation when the donor was one of the parents.

To analyze NK cell reconstitution kinetics in all 21 patients, 105 determinations were made, with an average of five per patient (minimum two and maximum 11). The obtained values were grouped by periods: from 21 to 90 days, from 91 to 120 days, from 121 to 180 days, from 181 to 240 days, from 241 to 300 days, from 301 to 360 days and more than 360 . All categories were compared with the values obtained in the clinically healthy individuals (Table 3 and Figure 2). The origin of the cells identified during the first weeks could be
Table 1. Demographic characteristics of patients undergoing HSCT and clinically healthy subjects of the control group

\begin{tabular}{|c|c|c|}
\hline Demographic data & Patients with HSCT & Control subjects \\
\hline $\begin{array}{l}\text { Gender } \\
\text { Males } \\
\text { Females }\end{array}$ & $\begin{array}{c}9(43 \%) \\
12(57 \%)\end{array}$ & $\begin{array}{l}17(85 \%) \\
3(15 \%)\end{array}$ \\
\hline $\begin{array}{l}\text { Age } \\
\text { Range } \\
\text { Mean } \\
\text { Median }\end{array}$ & $\begin{array}{c}1 \text { to } 17 \text { years } \\
7 \text { years } 6 \text { months } \\
8 \text { years } 5 \text { months }\end{array}$ & $\begin{array}{c}8 \text { to } 17 \text { years } \\
10 \text { years } 1 \text { month } \\
9 \text { years }\end{array}$ \\
\hline
\end{tabular}

due to expansion of the cells included in the graft (given that no CD34+ cell enrichment is made), while those subsequently detected would be generated by the recipient from cell precursors, mainly from the donor, as demonstrated by $95 \%$ of chimerism detected in peripheral blood cells (Fig. 3).

Significant differences were observed with regard to NK cell absolute numbers in patients undergoing HSCT: during the entire study period, the numbers were lower than those in the control group (Table 3 and Figure 3).

\section{Discussion}

According to our observations in the analyzed patients, NK cell early recovery occurs in the period of three to six months post-transplantation; however, there are periods when the absolute number is observed to be lower, and various events such as infections and graft-versus-host disease (GVHD) could therefore negatively affect NK cell reconstitution.

No significant difference was found when the number of NK cells was analyzed in 36 samples from patients with GVHD versus 69 samples from patients without GVHD (data not shown), or when quantifications of samples with or without viral agents were compared: BK polyomavirus, cytomegalovirus, adenovirus, Epstein-Barr virus (data not shown); therefore, NK cell reconstitution in this group of patients was considered not to be significantly affected by these clinical entities.

This could be due to the fact that, in the four patients in whom BK polyomavirus viral DNA was detected, immunosuppressive treatment was reduced in order to allow efficient cell function (expansion and effector capacity, such as the production of interferon-gamma and cytotoxicity). When the detected viral DNA was from Epstein-Barr virus, cytomegalovirus or adenovirus (viral load lower than 1000 copies/mL of plasma), 
Table 2. Transplantation cell dose, conditioning regimen and HLA compatibility

\begin{tabular}{|c|c|c|c|}
\hline Patient & CD34+/kg cell dose & Conditioning regimen & HLA allele compatibility* \\
\hline 1 & $1.71 \times 10^{7}$ & Fludarabine/cyclophosphamide & Haploidentical \\
\hline 2 & $7.4 \times 10^{6}$ & Busulfan/cyclophosphamide & Allogeneic $(12 / 12)$ \\
\hline 3 & $6.7 \times 10^{6}$ & Cyclophosphamide/etoposide/radiotherapy & Allogeneic (8/8) \\
\hline 4 & $3.19 \times 10^{6}$ & Busulfan/cyclophosphamide & Allogeneic $(12 / 12)$ \\
\hline 5 & $5 \times 10^{6}$ & Busulfan/cyclophosphamide & Allogeneic $(12 / 12)$ \\
\hline 6 & $1.03 \times 10^{7}$ & Busulfan/fludarabine & Haploidentical \\
\hline 7 & $4 \times 10^{6}$ & Busulfan/cyclophosphamide & Allogeneic $(12 / 12)$ \\
\hline 8 & $8 \times 10^{6}$ & Busulfan/cyclophosphamide/radiotherapy & Haploidentical \\
\hline 9 & $7.09 \times 10^{6}$ & Fludarabine/cyclophosphamide & Haploidentical \\
\hline 10 & $1.47 \times 10^{6}$ & Busulfan/cyclophosphamide/radiotherapy & Allogeneic (8/8) \\
\hline 11 & $5 \times 10^{6}$ & Busulfan/cyclophosphamide & Allogeneic (12/12) \\
\hline 12 & $1.11 \times 10^{6}$ & Busulfan/cyclophosphamide & Allogeneic $(12 / 12)$ \\
\hline 13 & $1.73 \times 10^{6}$ & Busulfan/cyclophosphamide & Allogeneic (12/12) \\
\hline 14 & $2.52 \times 10^{6}$ & Busulfan/cyclophosphamide & Allogeneic (12/12) \\
\hline 15 & $1.54 \times 10^{5}$ & Busulfan/cyclophosphamide & Allogeneic $(11 / 12)$ \\
\hline 16 & $6 \times 10^{6}$ & Fludarabine/cyclophosphamide & Haploidentical \\
\hline 17 & $6 \times 10^{6}$ & Busulfan/cyclophosphamide/radiotherapy & Allogeneic $(12 / 12)$ \\
\hline 18 & $1.23 \times 10^{6}$ & Busulfan/cyclophosphamide & Allogeneic $(12 / 12)$ \\
\hline 19 & $1 \times 10^{6}$ & Busulfan/cyclophosphamide & Allogeneic (12/12) \\
\hline 20 & $9.92 \times 10^{6}$ & Fludarabine/cyclophosphamide & Haploidentical \\
\hline 21 & $4.8 \times 10^{6}$ & Busulfan/cyclophosphamide & Allogeneic (11/12) \\
\hline
\end{tabular}

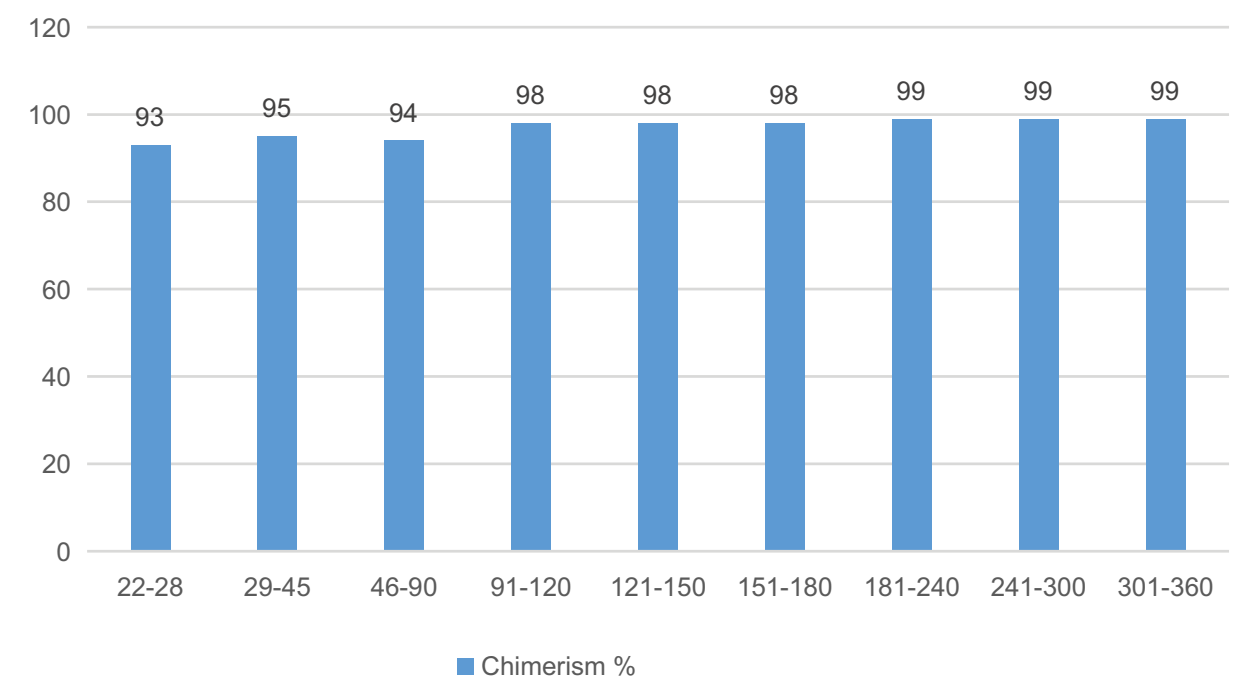

Figure 3. Cell chimerism kinetics after hematopoietic stem cell transplantation. Means obtained at different post-transplantation time-points. 
Table 3. NK cell/L measured values at different performed determinations

\begin{tabular}{|c|c|c|c|c|c|c|c|c|}
\hline \multirow{2}{*}{$\begin{array}{l}\text { Statistical } \\
\text { value }\end{array}$} & \multicolumn{7}{|c|}{ Post-transplantation days } & \multirow{2}{*}{$\begin{array}{l}\text { Control } \\
\text { group }\end{array}$} \\
\hline & $21-90$ & $91-120$ & $121-180$ & $180-240$ & $241-300$ & $301-360$ & +360 & \\
\hline $\begin{array}{l}\text { Lowest } \\
\text { value }\end{array}$ & $0.018 \times 10^{8}$ & $0.0321 \times 10^{8}$ & $0.0065 \times 10^{8}$ & $0.00016 \times 10^{8}$ & $0.000011 \times 10^{8}$ & $0.0208 \times 10^{8}$ & $0.00040 \times 10^{8}$ & $0.183 \times 10^{8}$ \\
\hline $\begin{array}{l}25^{\text {th }} \\
\text { percentile }\end{array}$ & $0.161 \times 10^{8}$ & $0.0778 \times 10^{8}$ & $0.051 \times 10^{8}$ & $0.0167 \times 10^{8}$ & $0.00743 \times 10^{8}$ & $0.0563 \times 10^{8}$ & $0.0730 \times 10^{8}$ & $0.283 \times 10^{8}$ \\
\hline Median & $0.635 \times 10^{8}$ & $0.205 \times 10^{8}$ & $0.0115 \times 10^{8}$ & $0.0909 \times 10^{8}$ & $0.0854 \times 10^{8}$ & $0.0819 \times 10^{8}$ & $0.124 \times 10^{8}$ & $0.582 \times 10^{8}$ \\
\hline $\begin{array}{l}75^{\text {th }} \\
\text { percentile }\end{array}$ & $0.144 \times 10^{8}$ & $0.406 \times 10^{8}$ & $0.0335 \times 10^{8}$ & $0.258 \times 10^{8}$ & $0.231 \times 10^{8}$ & $0.135 \times 10^{8}$ & $0.295 \times 10^{8}$ & $0.874 \times 10^{8}$ \\
\hline $\begin{array}{l}\text { Highest } \\
\text { value }\end{array}$ & $0.794 \times 10^{8}$ & $0.633 \times 10^{8}$ & $1.76 \times 10^{8}$ & $0.765 \times 10^{8}$ & $0.335 \times 10^{8}$ & $0.5 .82 \times 10^{8}$ & $0.548 \times 10^{8}$ & $1.31 \times 10^{8}$ \\
\hline Mean & $0.114 \times 10^{8}$ & $0.252 \times 10^{8}$ & $0.289 \times 10^{8}$ & $0.165 \times 10^{8}$ & $0.126 \times 10^{8}$ & $0.1 .47 \times 10^{8}$ & $0.183 \times 10^{8}$ & $0.605 \times 10^{8}$ \\
\hline $\begin{array}{l}\text { Standard } \\
\text { deviation }\end{array}$ & $0.160 \times 10^{8}$ & $0.203 \times 10^{8}$ & $0.442 \times 10^{8}$ & $0.232 \times 10^{8}$ & $0.126 \times 10^{8}$ & $0.1 .95 \times 10^{8}$ & $0.148 \times 10^{8}$ & $0.334 \times 10^{8}$ \\
\hline $\begin{array}{l}\text { Standard } \\
\text { error }\end{array}$ & $0.0296 \times 10^{8}$ & $0.0642 \times 10^{8}$ & $0.111 \times 10^{8}$ & $0.067 \times 10^{8}$ & $0.0419 \times 10^{8}$ & $0.074 \times 10^{8}$ & $0.0316 \times 10^{8}$ & $0.0927 \times 10^{8}$ \\
\hline $\begin{array}{l}95 \% \mathrm{Cl} \\
\text { lower limit }\end{array}$ & $0.0530 \times 10^{8}$ & $0.107 \times 10^{8}$ & $0.0531 \times 10^{8}$ & $0.0172 \times 10^{8}$ & $0.0292 \times 10^{8}$ & $0.034 \times 10^{8}$ & $0.118 \times 10^{8}$ & $0.403 \times 10^{8}$ \\
\hline $\begin{array}{l}95 \% \mathrm{Cl} \\
\text { upper limit }\end{array}$ & $0.174 \times 10^{8}$ & $0.398 \times 10^{8}$ & $0.525 \times 10^{8}$ & $0.312 \times 10^{8}$ & $0.223 \times 10^{8}$ & $0.327 \times 10^{8}$ & $0.249 \times 10^{8}$ & $0.807 \times 10^{8}$ \\
\hline $\begin{array}{l}\text { Comparison } \\
\text { vs. control } \\
\text { group, }\end{array}$ & $\begin{array}{c}\text { Yes } \\
(p<0.0001)\end{array}$ & No & No & $\begin{array}{c}\text { Yes } \\
(p=0.0059)\end{array}$ & $\begin{array}{c}\text { Yes } \\
(p=0.0059)\end{array}$ & No & $\begin{array}{c}\text { Yes } \\
(p=0.043)\end{array}$ & - \\
\hline
\end{tabular}

difference

(p)

standard treatment and constant viral load monitoring were continued, since having control of the infection by the recipient him/herself was intended. In order to reduce GVHD severity, immunosuppressive treatment was intensified, which is a measure that is also taken when the number of NK cells is dramatically decreased in order to favor their proliferation.

NK cell recovery in patients undergoing HSCT has been described to occur in the first two months, $8,13-15$ but it can be delayed for up to six months in patients with infections (mainly fungal) within the first 100 post-transplantation days. ${ }^{15}$ This phenomenon was observed in the analyzed patients, in whom various adverse events (infections and GVHD) were documented during the first 100 days (Epstein-Barr virus, cytomegalovirus and adenovirus were identified in four patients and GVHD in two, who throughout the first year did not have an efficient NK cell reconstitution).

According to the literature, during the first month of the post-transplantation stage, the number of NK cells should be $>0.75 \times 10^{8} / \mathrm{L}$ when the source of CD34+ cells is the bone marrow; when CD34+ cells are collected from peripheral blood, reconstitution is obtained from the fourth month on in pediatric patients. ${ }^{16}$ In a series of patients, it was possible to identify that reconstitution reached a median of $305 \mathrm{NK}$ cells $/ \mu \mathrm{L}$ (range: $30 \pm 1200$ ) by day 130 on average. ${ }^{7}$ These values are higher than those obtained in patients and in the control group of the research herein presented, and numerical comparison between the different series is therefore not pertinent given the different characteristics of each group, in which various external factors have an influence:

- The disease HSCT is carried out for.

- The conditioning regimen (which together with the administration of $50 \mathrm{mg} / \mathrm{kg} /$ day of cyclophosphamide on days 3 and 4 post-transplantation as a prophylactic measure for the prevention of acute GVHD generated a decrease in lymphopoiesis in our patients and, therefore, NK cell recovery was affected during the first 90 days of the post-transplantation stage). 
- Type of transplantation.

- Type of donor and HLA compatibility (13 HSCTs of the series herein described [62\%] were allogeneic with a $100 \%$ compatible donor, two HSCTs [9.5\%] were allogeneic with a $90 \%$ compatible donor and six [28.5\%] were haploidentical).

When the number of NK cells was compared in patients who underwent HSCT versus that of control individuals, a significant difference was observed in some periods (Fig. 2), which shows that the reconstitution was transient and deficient in some cases, probably due to NK cells sequestration at the infection target site (i.e., urinary tract in the patient in whom BK virus was identified) or to cell migration to specific tissues in the GVHD cases (skin and liver tissue). The highest number of NK cells in the post-transplantation stage was observed in the quantifications performed at between 91 and 120 days, with a homogeneous distribution, from which it is inferred that there was delayed NK cell reconstitution in our patients, considering data reported in the literature. Another factor that influences NK cell quantification is immunomodulation at post-transplantation stage, which is performed as part of transplantation maintenance follow-up.

There are two factors that directly influence on the delay of immune reconstitution after HSCT:

- Cell damage in the microenvironment generated by the conditioning regimen.

- Slow de novo generation of donor-derived immune system cells, ${ }^{7,17}$ which is why one of the strategies to promote an efficient immune reconstitution is the protection of the recipient's microenvironment. ${ }^{18}$

In the present research, only NK cell absolute numbers and percentages were analyzed; however, immune system homeostasis also depends on their functional capacity, since NK cell effector capacities can be efficient in the production of cytokines, antibodies or cytotoxic capacity even without the values observed in healthy subjects being reached.

In HSCT recipients, who are immunosuppressed, antigenic stimulation events occur due to opportunistic viral or bacterial infections; therefore, NK cells participation is essential since they are the first line of immune defense, and their reconstitution is important for transplantation long-term success. ${ }^{19-21}$

Assessing the role of different NK cell populations in hematopoietic stem cell receivers may assist the design of new therapeutic interventions aimed at enhancing HSCT effects. ${ }^{19,22}$

\section{Conflict of interests}

None.

\section{Funding Source}

This work was financed with funds from the HIM2017038 and HIM2017-130FF projects.

\section{Ethical disclosure}

Protection of human and animal subjects. The authors declare that no experiments were performed on humans or animals for this study.

Confidentiality of data. The authors declare that they have followed the protocols of their work center on the publication of patient data.

Right to privacy and informed consent. The authors have obtained written informed consent of the patients or subjects mentioned in the article. The corresponding author is in possession of this document.

\section{References}

1. Lanier LL, Phillips JH, Hackett J, Tutt M, Kumar V. Natural killer cells: definition of a cell type rather than a function. J Immunol. 1986;137:2735-2739.

2. Vivier E, Ugolini S. Natural killer cells: from basic research to treatments. Front Immunol. 2011;2:18.

3. Moretta A, Marcenaro E, Parolini S, Ferlazzo G, Moretta L. NK cells at the interface between innate and adaptive immunity. Cell Death Differ. 2008;15:226-233.

4. Lanier LL. Up on the tightrope: natural killer cell activation and inhibition. Nat Immunol. 2008;9:495-502.

5. Huenecke S, Cappel C, Esser R, Pfirrmann V, Salzmann-Manrique E, Betz S, et al. Development of three different NK cell subpopulations during immune reconstitution after pediatric allogeneic hematopoietic stem cell transplantation: prognostic markers in GvHD and viral infections. Front Immunol. 2017;8:109.

6. Ding Y, Zhou L, Xia Y, Wang W, Wang Y, Li L, et al. Reference values for peripheral blood lymphocyte subsets of healthy children in China. J Allergy Clin Immunol. 2018:142:970-973.

7. Eyrich M, Lang P, Lal S, Bader P, Handgretinger R, Klingebiel T, et al. A prospective analysis of the pattern of immune reconstitution in a paediatric cohort following transplantation of positively selected human leucocyte antigen-disparate haematopoietic stem cells from parental donors. Br J Haematol. 2001;114:422-432.

8. Hokland M, Jacobsen N, Ellegaard J, Hokland P. Natural killer function following allogeneic bone marrow transplantation. Very early reemergence but strong dependence of cytomegalovirus infection. Transplantation. 1988;45:1080-1084.

9. Bellone G, Valiante NM, Viale O, Ciccone E, Moretta L, Trinchieri G. Regulation of hematopoiesis in vitro by alloreactive natural killer cell clones. J Exp Med. 1993;177:1117-1125.

10. Manjili MH. The adaptation model of immunity. Immunotherapy. 2014; 6:59-70.

11. Ciccone E, Pende D, Viale O, Di Donato C, Tripodi G, Orengo AM, et al. Evidence of a natural killer (NK) cell repertoire for (allo) antigen recognition: definition of five distinct NK-determined allospecificities in humans. J Exp Med. 1992;175:709-718.

12. Ruggeri L, Capanni M, Casucci M, Volpi I, Tosti A, Perruccio K, et al. Role of natural killer cell alloreactivity in HLA-mismatched hematopoietic stem cell transplantation. Blood. 1999;94:333-339.

13. Saliba RM, Rezvani K, Leen A, Jorgensen J, Shah N, Hosing C, et al. General and virus-specific immune cell reconstitution after double cord blood transplantation. Biol Blood Marrow Transplant. 2015;21:1284-1290.

14. Petersen SL, Ryder LP, Björk P, Madsen HO, Heilmann C, Jacobsen N, et al. A comparison of T-, B- and NK-cell reconstitution following conventional or nonmyeloablative conditioning and transplantation with bone 
marrow or peripheral blood stem cells from human leucocyte antigen identical sibling donors. Bone Marrow Transplant. 2003;32:65-72.

15. Orange JS. Human natural killer cell deficiencies. Curr Opin Allergy Clin Immunol. 2006:6:399-409.

16. De Koning C, Plantinga M, Besseling P, Boelens JJ, Nierkens S. Immune reconstitution after allogeneic hematopoietic cell transplantation in children. Biol Blood Marrow Transplant. 2016;22:195-206.

17. Huttunen $P$, Taskinen M, Siitonen S, Saarinen-Pihkala UM. Impact of very early $\mathrm{CD}^{+} / \mathrm{CD} 8^{+} \mathrm{T}$ cell counts on the occurrence of acute graftversus-host disease and NK cell counts on outcome after pediatric allogeneic hematopoietic stem cell transplantation. Pediatr Blood Cancer. 2015;62:522-528.

18. Mehta RS, Rezvani K. Immune reconstitution post allogeneic transplant and the impact of immune recovery on the risk of infection. Virulence. 2016;7:901-916.
19. Jacobs R, Stoll M, Stratmann G, Leo R, Link H, Schmidt RE. CD16- CD56+ natural killer cells after bone marrow transplantation. Blood. 1992;79: 3239-344.

20. Nguyen S, Kuentz M, Vernant JP, Dhedin N, Bories D, Debré $P$, et al. Involvement of mature donor T cells in the NK cell reconstitution after haploidentical hematopoietic stem-cell transplantation. Leukemia. 2008;22:344-352.

21. Kheav VD, Busson M, Scieux C, Peffault-de Latour R, Maki G, Haas P et al. Favorable impact of natural killer cell reconstitution on chronic graft-versus-host disease and cytomegalovirus reactivation after allogeneic hematopoietic stem cell transplantation. Haematologica. 2014;99: 1860-1867.

22. Stabile H, Fionda C, Gismondi A, Santoni A. Role of distinct natural killer cell subsets in anticancer response. Front Immunol. 2017;8: 293. 